\title{
Keamanan Peralatan Radiasi Pengion Dikaitkan Dengan Perlindungan Hukum Bagi Tenaga Kesehatan Di Bidang Radiologi Diagnostik
}

(Penelitian Hukum Normatif Terhadap PP No. 33 Tahun 2007 Tentang Keselamatan Radiasi

Pengion dan Keamanan sumber Radioaktif dan PP No. 29 Tahun 2008 Tentang Perizinan

Pemanfaatan Sumber Radiasi Pengion dan Bahan Nuklir serta Permenkes No. 363 Tahun 1998

Tentang Pengujian Dan Kalibrasi Alat Kesehatan pada Sarana Pelayanan Kesehatan)

\author{
Puji Supriyono, Wila Candrawila S., Agus H. Rahim dan Tri Wahyu Murni \\ puji_supriyono@gmail.com \\ Magister Hukum Kesehatan \\ Universitas Katolik Soegijapranata Semarang
}

\begin{abstract}
ABSTRAK
Aspek keselamatan dalam pemakaian tenaga nuklir di Indonesia dilindungi oleh Undangundang Republik Indonesia Nomor 10 tahun 1997 tentang Ketenaganukliran, yang pelaksanaannya diatur oleh Peraturan Pemerintah Republik Indonesia Nomor 33 tahun 2007 tentang Keselamatan Radiasi Pengion dan Keamanan Sumber Radioaktif, Peraturan Pemerintah Republik Indonesia Nomor 29 tahun 2008 tentang Perizinan Pemanfaatan Sumber Radiasi Pengion dan Bahan Nuklir, dan Peraturan Menteri Kesehatan Republik Indonesia nomor 363/MENKES/PER/IV/1998 tentang Pengujian dan Kalibrasi Alat Kesehatan pada Sarana Pelayanan Kesehatan, serta Peraturan Menteri Kesehatan Republik Indonesia Nomor 780/MENKES/PER/VIII/2008 tentang Penyelenggaraan Pelayanan Radiologi.

Salah satu fungsi hukum adalah untuk melindungi para pihak yang terkait dalam hubungan hukum, agar ketentuan-ketentuan yang dibuat benar-benar dapat melindungi para pihak, sehingga terbentuk keadilan hukum.Keadilan hukum tentunya selalu bersisi dua, adil bagi seseorang akan tidak adil bagi orang lain, sehingga perlu diambil ukuran lain yang bagi para pihak terdapat keadilan yang seimbang. Seringkali pihak-pihak yang terkait akan mengmabil ukuran adil yang tentunya menguntungkan bagi didinya, sehingga terdapat banyak pendapat bagi artinya adil, yang paling memadai adalah apa yang dikemukakan oleh John Rawls, bahwa apa keadilan sebagai kepantasan: Justice as fainess.

Peneilitian hukum ini menggunakan Metode Penelitian Deskriptif dengan pendekatan Metode Penelitian Yuridis Normatif, sehingga jenis penelitian yang digunakan adalah Studi Kepustakaan. Data yang dikumpulkan adalah data kualitatif dalam bentuk bahan pustaka, yakni bahan hukum primer, sekunder dan tertier. Sehubungan dengan data yang digunakan data kualitatif, maka akan dilakukan analisis kualitatif terhadap ketiga bahan hukum yang dikumpulkan, dan akan dirumuskan jawaban sementara berbentuk hipotesis kerja.

Pemanfaatan tenaga nuklir wajib dilaksanakan dengan memperhatikan aspek keselamatan dan keamanan untuk melindungi pekerja, anggota masyarakat, dan lingkungan hidup, sehingga pengaturan yang lebih jelas, efektif, dan konsisten. Pengaturan mengenai Keselamatan Radiasi Pengion ditetapkan dengan Peraturan Pemerintah Nomor 33 Tahun 2007 tentang Keselamatan Radiasi Pengion dan Keamanan Sumber Radioaktif (untuk selanjunya akan disebut dengan PP Keselamatan Radiasi). Apabila ketentuan-ketentuan hukum dilaksanakan dengan sebaik-baiknya maka Jaminan perlindungan keselamatan bagi pekerja kesehatan dibidang radiodiagnostik akan tercapai.
\end{abstract}


Kata kunci : Keamanan peralatan, Aspek keselamatan dan keamanan serta perlindungan hukum bagi tenaga kesehatan dibidang Radiologi Diagnostik, unsur-unsur asas persamaan di muka hukum, hubungan ketentuan keamanan peralatan radiasi pengion dan perlindungan hukum bagi tenaga kesehatan di bidang radiologi diagnostik.

\section{PENDAHULUAN}

Pada era globalisasi ini, kondisi masyarakat akan berubah sesuai dengan perkembangan pembangunan khususnya pembangunan kesehatan. Dengan pembangunan di bidang kesehatan, masyarakat akan semakin mengerti kesadaran pentingnya kesehatan diri sendiri. Pemerintah melindungi masyarakat dari adanya alat kesehatan yang tidak memenuhi keamanan, mutu, dan manfaat. Perlindungan masyarakat termasuk tenaga kesehatan, khususnya yang bekerja di bidang Radiologi diagnostik.

Aspek keselamatan dalam pemakaian tenaga nuklir di Indonesia dilindungi oleh Undangundang Republik Indonesia Nomor 10 tahun 1997 tentang Ketenaganukliran, yang pelaksanaannya diatur oleh Peraturan Pemerintah Republik Indonesia Nomor 33 tahun 2007 tentang Keselamatan Radiasi Pengion dan Keamanan Sumber Radioaktif, Peraturan Pemerintah Republik Indonesia Nomor 29 tahun 2008 tentang Perizinan Pemanfaatan Sumber Radiasi Pengion dan Bahan Nuklir, dan Peraturan Menteri Kesehatan Republik Indonesia nomor 363/MENKES/PER/IV/1998 tentang Pengujian dan Kalibrasi Alat Kesehatan pada Sarana Pelayanan Kesehatan, serta Peraturan Menteri Kesehatan Republik Indonesia Nomor 780/MENKES/PER/VIII/2008 tentang Penyelenggaraan Pelayanan Radiologi.

Namun, perkembangan ilmu pengetahuan dan teknologi di bidang ketenaganukliran yang pesat telah mengakibatkan terjadinya perubahan pada standar internasional yang harus disesuaikan dengan peraturan perundangundangan di Indonesia. Adapun perubahan meliputi, persyaratan izin tidak hanya mempertimbangkan faktor keselamatan radiasi, namun juga keamanan sumber radioaktif dan bahan nuklir.

Pemanfaatan tenaga nuklir dibagi menjadi 2 bagian, yaitu untuk energi dan non-energi. Pemanfaatan energi nuklir untuk energi adalah dalam bentuk Pembangkit Listrik Tenaga Nuklir. Sedangkan pemanfaatan energi nuklir dalam bentuk non energi sangat banyak digunakan di Indonesia, salah satunya seperti penggunaan zat radio-aktif dan sinar-X untuk Radiologi Diagnostik. Untuk semua pemanfaatan tenaga nuklir ini, hal yang harus diutamakan adalah keselamatan.

Sesuai dengan prinsip keselamatan radiasi bahwa di dalam pemanfaatan tenaga nuklir harus didasarkan azas manfaat. Dengan kata lain, penggunaan tenaga nuklir termasuk radiasi pengion, di berbagai bidang, keuntungan yang didapat harus jauh lebih besar dari pada risiko yang ditimbulkannya. Demikian juga penggunaan tenaga nuklir tidak boleh disalahgunakan untuk tujuan lain yang dapat membahayakan manusia.

Keadilan hukum tentunya selalu bersisi dua, adil bagi seseorang akan tidak adil bagi orang lain, sehingga perlu diambil ukuran lain yang bagi para pihak terdapat keadilan yang seimbang. Seringkali pihak-pihak yang terkait akan mengambil ukuran adil yang tentunya menguntungkan bagi dirinya, sehingga terdapat banyak pendapat bagi artinya adil, yang paling memadai adalah apa yang dikemukakan oleh John Rawls, bahwa apa keadilan sebagai kepantasan: Justice as fainess.

Aspek keselamatan dalam pemakaian tenaga nuklir di Indonesia dilindungi oleh Undangundang Republik Indonesia Nomor 10 tahun 1997 tentang Ketenaganukliran, yang pelaksanaannya diatur oleh Peraturan Pemerintah Republik Indonesia Nomor 33 tahun 2007 tentang Keselamatan Radiasi Pengion dan Keamanan Sumber Radioaktif, Peraturan Pemerintah Republik Indonesia Nomor 29 tahun 2008 tentang Perizinan Pemanfaatan Sumber Radiasi 
Pengion dan Bahan Nuklir, dan Peraturan Menteri Kesehatan Republik Indonesia nomor 363/MENKES/PER/IV/1998 tentang Pengujian dan Kalibrasi Alat Kesehatan pada Sarana Pelayanan Kesehatan, serta Peraturan Menteri Kesehatan Republik Indonesia Nomor 780/MENKES/PER/VIII/2008 tentang Penyelenggaraan Pelayanan Radiologi.

Dalam pengaturan tersebut, wewenang pelaksanaan dan pengawasan dipisahkan dalam dua lembaga yang berbeda untuk menghindari tumpang tindih kegiatan pemanfaatan dan pengawasan dan sekaligus mengoptimalkan pengawasan yang bertujuan untuk lebih meningkatkan keselamatan nuklir. Namun, perkembangan ilmu pengetahuan dan teknologi di bidang ketenaganukliran yang pesat telah mengakibatkan terjadinya perubahan pada standar internasional yang harus disesuaikan dengan peraturan perundangundangan di Indonesia. Adapun perubahan meliputi, persyaratan izin tidak hanya mempertimbangkan faktor keselamatan radiasi, namun juga keamanan sumber radioaktif dan bahan nuklir.

Pemanfaatan tenaga nuklir dibagi menjadi 2 bagian, yaitu untuk energi dan non-energi. Pemanfaatan energi nuklir untuk energi adalah dalam bentuk Pembangkit Listrik Tenaga Nuklir. Sedangkan pemanfaatan energi nuklir dalam bentuk non energi sangat banyak digunakan di Indonesia, salah satunya seperti penggunaan zat radio-aktif dan sinar-X untuk Radiologi Diagnostik. Untuk semua pemanfaatan tenaga nuklir ini, hal yang harus diutamakan adalah keselamatan.

Penulis merumuskan masalah penelitian yang menjadi fokus kajian adalah tentang keamanan peralatan radiasi pengion menyebabkan dipenuhinya perlindungan hukum bagi tenaga kesehatan di bidang radiologi diagnostik. Metode pendekatan yang dipergunakan dalam penelitian ini adalah Metode Penelitian Yuridis Normatif. Sehubungan dengan upaya ilmiah, maka metode menyangkut masalah cara kerja, yaitu cara kerja untuk memahami obyek yang menjadi sasaran ilmu yang bersangkutan. ${ }^{1}$ Dengan demikian, pengertian dari kata "metode" berarti suatu penyelidikan atau penelitian yang berlangsung menurut suatu rencana atau cara tertentu ${ }^{2}$.

Selanjutnya, kata atau istilah "pendekatan/approach" adalah sesuatu hal (perbuatan atau usaha) mendekati atau mendekatkan ${ }^{3}$. Dalam konteks penelitian, kata atau istilah "pendekatan/approach" merupakan bentuk sistematis yang khusus dari seluruh pemikiran dan telaah reflektif. ${ }^{4}$

Sedangkan yuridis normatif dalam penelitian ini berarti, bahwa hukum memiliki sifat/karakteristik khusus atau kekhasan, yaitu sebagai suatu norma/kaidah yang mempedomani atau sebagai patokan perilaku manusia dalam berinteraksi dengan sesamanya. Dengan demikian, pendekatan yuridis normatif berarti dalam penelitian hukum yang dilakukan terhadap bahan pustaka atau data sekunder belaka dan dengan menggunakan metode berpikir deduktif serta kriterium kebenaran koheren ${ }^{5}$.

\footnotetext{
1 Lihat Koentjaraningrat, Metode-metode Penelitian Masyarakat, Gramedia, Jakarta, 1977, hlm.16.

2 Lihat J. J. J. M. Wuisman, Penelitian Ilmu-ilmu Sosial (Jilid I : Asas-asas) disunting oleh : M. Hisyam, Lembaga Penerbit Fakultas Ekonomi Universitas Indonesia, Jakarta, 1996, hlm.85-86; lihat pula C.A. van Peursen, Susunan IImu Pengetahuan (Sebuah Pengantar Filsafat Ilmu) diterjemahkan oleh : J. Drost, Gramedia, Jakarta, 1993, hlm. 16.

3 Lihat Hilman Hadikusuma, Metode Pembuatan Kertas Kerja atau Skripsi Ilmu Hukum, Mandar Maju, Bandung, 1995, hlm. 58-61.

4 Lihat Fred N. Kerlinger, Asas-asas Penelitian Behavioral diterjemahkan oleh: Landung R. Simatupang, Gadjah Mada University Press, Yogyakarta, 1992, hlm. 18.

${ }^{5}$ Lihat Soerjono Soekanto \& Sri Mamudji, Penelitian Hukum Normatif (Suatu Tinjauan Singkat), Rajawali Pers, Jakarta, 2001, hlm. 13-14.
} 


\section{PEMBAHASAN}

\section{Pengertian Radiasi dan Radiasi Pengion}

Radiasi dalam istilah fisika pada dasarnya adalah suatu cara perambatan energi dari suatu sumber energi ke lingkungannya tanpa membutuhkan medium atau perantara. Beberapa contohnya adalah perambatan panas, perambatan cahaya, dan perambatan gelombang radio. Selain radiasi, energi juga dapat dipindahkan dengan cara konduksi, kohesi dan konveksi. Berdasarkan efek radiasi yang ditimbulkannya, maka radiasi dapat dikelompokan menjadi radiasi pengion dan radiasi non-pengion. Adapun yang temasuk ke dalam kelompok radiasi pengion adalah cahaya matahari, sinar-x dan radiasi dari bahan radioaktif, sedangkan radiasi yang termasuk radiasi non-pengion adalah seperti sinar ultraviolet, radiasi panas, gelombang radio dan microwave ${ }^{6}$.

Radiasi Pengion menurut Pasal 1 Angka (6) PP Nomor 33 Tahun 2007 tentang Keselamatan Radiasi Pengion dan Keamanan Sumber Radioaktif (yang untuk selanjutnya akan disebut PP Keselamatan Radiasi) didefinisikan sebagai gelombang elektromagnetik dan partikel bermuatan yang karena energi yang dimilikinya mampu mengionisasi media yang dilaluinya.

Sinar radiasi pengion adalah sinar yang mempunyai sifat tidak dapat dilihat, tidak berwarna, tidak dapat dirasakan, namun mempunyai sifat yang dapat merusak sel-sel tubuh manusia dengan jalan bila mengenai dan menembus tubuh manusia, dalam besar dosis tertentu serta periode jangka waktu tertentu dapat mengakibatkan terjadinya proses ionisasi sel-sel tubuh manusia, dengan cara energi penyinaran yang diabsorpsi di dalam tubuh akan membebaskan elektronelektron dari atom, dan atom yang telah mengalami ionisasi akan menjadi unsur radikal bebas yang akan merusak materi genetik DNA. Proses ini seiring dengan berjalannya waktu dapat mengakibatkan perubahan atau mutasi sel atau gen yang kemudian dapat mempengaruhi sistem kerja biokimia enzim tubuh atau pun sistem tubuh lainnya. Sedangkan radiasi sinar non pengion tidak mempunyai kemampuan melakukan proses ionisasi seperti sinar pengion ${ }^{7}$.

Jenis-jenis sinar pengion tersebut antara lain:

a. "Sinar Alfa, yang mempunyai radiasi daya tembus yang sangat pendek, namun masih tetap mempunyai potensi yang membahayakan apabila tertelan masuk ke sistem perncernaan atau terhirup masuk sistem pernafasan dalam jumlah yang cukup besar.

b. Sinar Beta mempunyai gelombang partikel yang lebih kecil daripada sinar Alfa, yang dalam jumlah besar dapat menyebabkan kulit terbakar dan sangat berbahaya apabila terhirup atau tertelan.

c. Sinar Gamma mempunyai sifat gelombang elektromagnetik seperti cahaya atau gelombang radio dengan daya tembus yang kuat, yang dapat menembus materi dan hanya bisa tertahan oleh bahan yang sangat padat dan tebal, dan karena itu dapat mencapai organorgan tubuh tanpa harus menghirup atau menelannya" 8

Menurut Pasal 1 Angka (7) PP Keselamatan Radiasi, yang dimaksud dengan Sumber Radiasi adalah segala sesuatu yang dapat menyebabkan paparan Radiasi, meliputi zat radioaktif dan peralatan yang mengandung zat radioaktif atau memroduksi Radiasi, dan fasilitas atau instalasi yang di dalamnya terdapat zat radioaktif atau peralatan yang menghasilkan Radiasi.

6 Lihat David Sutton, Textbook of Radiology, Lippincott \& Wilkins, Boston, USA, hlm. 5.

7 Lihat David Sutton, Textbook of Radiology, Lippincott \& Wilkins, Boston, USA hlm. 23.

8 Ibid. hlm. 24. 
Radiasi merupakan fakta dari kehidupan manusia, karena secara alamiah manusia hidup di dunia selalu berhubungan dengan radiasi. Panas dan cahaya dari reaksi nuklir matahari sangat esensial bagi kehidupan manusia. Semua kehidupan yang mengalami evolusi selalu berhubungan dengan radias ${ }^{9}$.

Berbagai jenis radiasi dapat ditemukan di alam dalam berbagai bentuk yang dihasilkan dengan cara yang berbeda, namun jenis radiasi yang paling banyak ditemukan adalah radiasi yang berasal dari bahan radioaktif. Berdasarkan asalnya sumber radiasi pengion dapat dibedakan menjadi dua yaitu sumber radiasi alam yang sudah ada di alam ini sejak terbentuknya, dan sumber radiasi buatan yang sengaja dibuat oleh manusia untuk berbagai 10 tujuan .

Adapun penjelasan dari masing-masing sumber tersebut di atas, yakni sebagai berikut: Pertama, Sumber Radiasi Alam. Radiasi yang dipancarkan oleh sumber radiasi alam disebut juga sebagai radiasi latar belakang (background radiation). Radiasi ini merupakan radiasi terbesar yang diterima oleh manusia yang tidak bekerja di tempat yang menggunakan radioaktif atau yang tidak menerima radiasi berkaitan dengan kedokteran atau kesehatan. Radiasi latar belakang yang diterima oleh seseorang dapat berasal dari tiga sumber utama yaitu:

a. Sumber radiasi kosmis. Radiasi kosmis berasal dari angkasa luar, sebagian berasal dari ruang antar bintang dan matahari. Radiasi ini terdiri dari partikel dan sinar yang berenergi tinggi dan berinteraksi dengan inti atom stabil di atmosfir, membentuk inti atom radioaktif seperti Carbon-14, Helium-3, Natrium-22, dan Be-7. Atmosfir bumi dapat mengurangi radiasi kosmik yang diterima oleh manusia. Tingkat radiasi dari sumber kosmik ini bergantung kepada ketinggian, yaitu radiasi yang diterima akan semakin besar apabila posisinya juga semakin tinggi.

b. Sumber radiasi terestrial. Radiasi terestrial secara alami dipancarkan oleh radionuklida (sumber radiasi yang bersenyawa dengan unsur tanah bumi) didalam kerak bumi. Radiasi ini dipancarkan oleh radionuklida yang disebut primordial yang ada sejak terbentuknya bumi. Radionuklida yang ada dalam kerak bumi terutama adalah deret Uranium, yaitu peluruhan berantai mulai dari Uranium-238, Plumbum-206, deret Actinum (U-235, Pb-207) dan deret Thorium (Th-232, Pb-208). Radiasi terestrial terbesar yang diterima manusia berasal dari Radon ( $\mathrm{R}-222)$ dan Thoron (Ra-220) karena dua radionuklida ini berbentuk gas sehingga dapat menyebar kemana-mana. Tingkat radiasi yang diterima seseorang dari radiasi terestrial ini berbeda-beda dari satu tempat ke tempat yang lain, bergantung kepada konsentrasi sumber radiasi di dalam kerak bumi.

c. Sumber radiasi Internal. Sumber radiasi ini juga ada didalam tubuh manusia sejak dilahirkan, dan bisa juga masuk kedalam tubuh manusai melalui makanan, minuman, pernafasan, atau luka. Radiasi internal ini terutama diterima dari radionuklida $\mathrm{C}-14, \mathrm{H}-3, \mathrm{~K}-40$, Radon, selain itu masih ada lagi sumber lainnya seperti Pb-210, Po-210 yang banyak berasal ikan dan kerangkerangan. Buah-buahan biasanya mengandung unsur K-40. Kedua, Sumber Radiasi Buatan. Sumber radiasi buatan telah diproduksi sejak awal abad 20, dengan ditemukannya sinar X oleh Wilhelm Conrad Roentgen. Saat ini sudah banyak sekali jenis dari sumber radiasi buatan baik yang berupa zat radioaktif dan sumber pembangkit radiasi (pesawat sinar X dan Linear akselerator atau LINAC). Radioaktif dapat dibuat oleh manusia berdasarkan reaksi inti antara nuklida yang tidak radioaktif dengan neutron atau biasa disebut sebagai reaksi fisi, didalam sebuah reaktor atom. Radionuklida buatan ini bisa

9 Lihat Wrixon A.D., et. al., Radiation, People and the Environment, IAEA, 2004, hlm. 1.

${ }^{10}$ Lihat Hasroel Thayib, Radiasi dan Radionuklida Lingkungan, Badan Tenaga Atom Nasional, Jakarta, 1996, hlm. 16. 
memancarkan radiasi sinar alfa, beta, gamma dan neutron. Sumber pembangkit radiasi yang lazim dipakai yakni pesawat sinar $\mathrm{X}$ dan Linear akselerator. ${ }^{11}$

Pengaruh radiasi pada organ tubuh manusia dapat bermacam-macam bergantung pada jumlah dosis dan luas lapangan radiasi yang diterima. Pada tahun 1950 Komisi Internasional untuk perlindungan terhadap penyinaran menetapkan bahwa pengaruh sinar $\mathrm{X}$ adalah sebagai berikut:

a. Luka permukaan yang dangkal seperti: Kerusakan kulit (skin damage); Epilasi (epilation); Kuku rapuh (brittleness of nails). Reaksi luka permukaan yang dangkal dapat timbul segera atau setelah beberapa lama. Reaksi yang segera timbul dapat menyerupai luka bakar. Dosis maksimal untuk kulit yang masih dapat diberikan tidak diketahui, tetapi bagi para pekerja yang setiap harinya berhubungan dengan sinar $\mathrm{X}$ diperkirakan dosisnya kurang dari $1 \mathrm{R}$ per hari. Radiasi sinar $\mathrm{X}$ yang berlangsung lama (kronis) atau bertahun-tahun telah terbukti dapat menimbulkan karsinoma kulit.

b. Kerusakan hemopoetik: Limfopeni; Leukopeni; Anemi; Leukemi; dan Kehilangan respons terhadap daya tahan spesifik (loss of specific immune response).

c. Induksi keganasan (induction of malignancy): Leukemi; Karsinoma kulit; Sarkoma.

d. Berkurangnya "kemungkinan hidup" (reduction of life span).

e. Aberasi genetik (genetic aberrations) seperti: Mutasi gen langsung; Perubahan kromosom (chromosomal alteration).

f. Efek-efek lainnya (other deleterious effects) seperti:Katarak lentikuler; Obesitas; Sterilitas sementara (temporary) maupun tetap (permanent) ${ }^{12}$

United States Nuclear Regulatory Commision (NRC) adalah salah satu sumber informasi resmi yang dijadikan standar dibeberapa negara untuk penetapan garis pedoman pada proteksi radiasi. NRC telah menyatakan bahwa dosis individu terpapar radiasi maksimal adalah $0.05 \mathrm{~Sv}$ atau $5 \mathrm{rem} /$ tahun. Beberapa efek yang merugikan dari radiasi hanya berlangsung singkat, sedangkan efek lainnya bisa menyebabkan penyakit menahun. Efek dini dari dosis radiasi tinggai akan tampak jelas dalam waktu beberapa menit atau beberapa hari. Efek lanjut mungkin baru tampak beberapa minggu, bulan atau bahkan bertahun tahun kemudian Mutasi (pergeseran) bahan genetika dari sel-sel organ kelamin akan tampak jelas pada keturunannya dengan adanya kelainan genetika pada keturunannya. Efek akut menghasilkan kerusakan sel parenkim akibat disi yang besar dari radiasi ionisasi, dengan ditandai adanya eritema, desquamasi kering, desquamasi lembab dan pengelupasan kulit. Pemaparan terhadap organ radiosensitif lainnya seperti kelenjar tyroid, organ lymphoid, usus dan ginjal dapat menyebabkan hilangnya sel parenkim yang mengarah pada gagal organ dan disfungsi. Efek akut terhadap tubuh dapat mengakibatkan kerusakan yang berbeda ;Sindrom susm tulang belakang, jika terpapar dengan dosis 2.5 - 5 Gy, Sindrom Gastrointestinal jika terpapar 5-12 Gy, Sindrom otak jika terpapar total radiasi sangat tinggi > 20 Gy, dengan gejala mual dan muntah, lalu diikuti oleh ngantuk, lelah dan kandang koma. Efek kronis akibat pemaparan berulang atau pemaparan jangka panjang oleh dosis rendah, yang dapat berakibat terhentinya menstruasi (Amenore), berkurangnya kesuburan pada pria dan wanita, berkurangnya gairah seksual (libido) pada wanita, katarak dan berkurangnya jumlah sel darah merah (anemia), sel darah putih (leukopenia) dan trombosit (trombositopenia).

\footnotetext{
${ }^{11}$ Lihat Ibid. hlm. 16-18

12 Marnansjah Daini Rachman, Bahaya Radiasi dan Pencegahannya dalam "Radiologi Diagnostik" editor: Sjahriar Rasad, et. al., Balai Penerbit FKUI, 1995., hlm. 26.
} 


\section{Aspek Hukum Pemanfaatan Sumber Radiasi Pengion}

Menurut Pasal 1 Angka (1) PP No. 29 Tahun 2008 tentang Perizinan dan Pemanfaatan Sumber Radiasi Pengion dan Bahan Nuklir (untuk selanjutnya akan disebut dengan PP Perizinan dan Pemanfaatan Radiasi), yang dimaksud dengan pemanfaatan adalah kegiatan yang berkaitan dengan tenaga nuklir yang meliputi penelitian, pengembangan, penambangan, pembuatan, produksi, pengangkutan, penyimpanan, pengalihan, ekspor, impor, penggunaan, dekomisioning, dan pengelolaan limbah radioaktif untuk meningkatkan kesejahteraan rakyat. Selanjutnya dalam Pasal 1 Angka (3) PP Perizinan dan Pemanfaatan Radiasi, adapun yang dimaksud dengan Sumber Radiasi Pengion adalah zat radioaktif terbungkus dan terbuka beserta fasilitasnya, dan pembangkit radiasi pengion.

Pemanfaatan tenaga nuklir di Indonesia menganut sistem pemberitahuan (notification) kepada Badan Pengawas Tenaga Nuklir. Sehingga Badan Pengawas Tenaga Nuklir memiliki kewenangan untuk memutuskan apakah badan atau seseorang tersebut harus memiliki izin (license), atau tidak perlu memiliki izin tetapi dengan suatu persyaratan tertentu (registration), atau dikecualikan dari kewajiban izin (exemption). Disamping itu masih ada bentuk lain yang dibebaskan dari izin (clearance) yaitu bila suatu tenaga nuklir (sumber radiasi) yang pada awalnya memiliki izin, akan tetapi kemudian aktivitas maupun paparan sumber radiasi tersebut menjadi dibawah nilai batas yang ditentukan, maka atas persetujuan Badan Pengawas sumber radiasi tersebut tidak memerlukan izin tagi, tetapi masih perlu terus diawast penyimpanannya.

Adapun persyaratan untuk mendapatkan izin pemanfaatan tenaga nuklir adalah meliputi persyaratan umum, yang terdiri dari syarat administratif dan syarat teknis. Hal ini sebagaimana diatur dalam Pasal 10 sampai dengan Pasal 16 PP Perizinan dan Pemanfaatan Radiasi. Izin pemanfaatan akan diberikan dalam jangka waktu tertentu dan setelah itu dapat diperpanjang lagi. Selama izin pemanfaatan berlaku, pemegang izin atau Pengusaha Instalasi baik instalasi nuklir maupun instalasi radiasi pengion berkewajiban mengelola instalasi dengan benar dan menjamin pekerja dan lingkungan kerja dalam keadaan selamat dan sehat. Disamping itu pemegang izin harus melaporkan kepada Badan Pengawas setiap terjadi kecelakaan. Badan Pengawas secara rutin ataupun sewaktu-waktu dapat menugaskan Inspektur Keselamatan Nuklir memasuki setiap instalasi nuklir atau instalasi yang memanfaatkan radiasi pengion untuk melakukan pemeriksaan. Dalam hal tidak dipenuhinya lagi syarat perizinan maka diberikan peringatan tertulis sampai tingkat pencabutan izin. Adapun persyaratan bagi perizinan tersebut, yakni persyaratan fasilitas, petugas ahli, peralatan dan prosedur kerja adalah persyaratan yang secara umum dapat menunjukkan apakah pemanfaatan tenaga nuklir yang akan dilaksanakan dapat menjamin keselamatan dan kesehatan pekerja, anggota masyarakat dan lingkungan hidup.

Pemanfaatan Sumber Radiasi Pengion dan Bahan Nuklir dikelompokkan menjadi 3 (tiga) kelompok. Pengelompokan tersebut didasarkan pada risiko yang terkait dengan keselamatan radiasi dan keamanan Sumber Radioaktif dan Bahan Nuklir, dengan mempertimbangkan: potensi bahaya radiasi; tingkat kerumitan fasilitas dan/atau Sumber Radiasi Pengion dan Bahan Nuklir; jumlah dan kompetensi personil yang bekerja; potensi dampak kecelakaan radiasi terhadap keselamatan, kesehatan pekerja dan anggota masyarakat, dan lingkungan hidup; dan potensi ancaman terhadap Sumber Radioaktif dan Bahan Nuklir. Hal ini sebagaimana diatur dalam Pasal 3 PP Perizinan dan Pemanfaatan Radiasi yang meliputi: (1) kelompok A; (2) kelompok B; dan (3) kelompok C.

\section{Ketentuan Tentang Keamanan Peralatan Radiasi Pengion}

Berdasarkan Pasal 4 Peraturan Menteri Kesehatan Nomor 780/Menkes/Per/VIII/2008 tentang Penyelenggaraan Pelayanan Radiologi, ditentukan bahwa salah satu syarat untuk memperoleh izin bagi penyelenggaraan pelayanan radiologi diagnostik adalah apabila telah 
memenuhi persyaratan peralatan sesuai dengan klasifikasi sarana pelayanan kesehatannya, yang terdiri dari:

a. Data denah, ukuran, konstruksi dan proteksi ruangan;

b. Data peralatan dan spesifikasi teknis radiologi diagnostik;

c. Berita acara uji fungsi alat; dan

d. Surat izin importir alat dari BAPETEN (untuk alat yang menggunakan radiasi pengion/sinar$\mathrm{X})$.

Di samping itu, untuk dapat menyelenggarakan pelayanan radiodiagnostik dan radiologi intervensional, maka fasilitas pelayanan kesehatan harus pula memiliki izin penggunaan alat dari BAPETEN dan dari Kepala Dinas Kesehatan Propinsi bagi fasilitas pelayanan kesehatan yang menyelenggarakan pelayanan imejing diagnostik selain USG.

Selanjutnya dalam Keputusan Menteri Kesehatan Nomor 1014/Menkes/SK/XI/2008 tentang Standar Pelayanan Radiologi Diagnostik di Sarana Pelayanan Kesehatan, ditentukan pula bahwa pendekatan yang dipakai dalam penentuan standar peralatan adalah sebagai berikut: Pertama, pengembangan pelayanan radiologi diagnostik di sarana pelayanan kesehatan tersebut; Kedua, cara kerja peralatan radiologi diagnostik; dan Ketiga, kelengkapan/peralatan dasar yang tersedia. Adapun untuk pemeliharaan dan perawatan peralatan radiologi tersebut, maka harus mengacu pada pedoman dari pabrikan yang dilakukan secara berkala dan berkelanjutan oleh radiographer, fisikawan medis, teknisi elektromedis dan teknisi pabrikan untuk menjamin mutu alat yang dipakai sehingga pelayanan kesehatan kepada masyarakat tidak terganggu.

\section{Ketentuan tentang Pengujian dan Kalibrasi Peralatan Radiasi Pengion}

Peraturan Menteri Kesehatan RI Nomor 363/Menkes/Per/IV/1998 tanggal 8 April 1998 tentang Pengujian dan Kalibrasi Alat Kesehatan, mewajibkan setiap alat kesehatan yang dipergunakan di Sarana Pelayanan Kesehatan dilakukan pengujian dan kalibrasi secara berkala sekurang-kurangnya 1 (satu) kali dalam setahun oleh institusi Penguji, untuk menjamin ketelitian dan ketepatan serta keamanan penggunaan alat kesehatan.

Berdasarkan SK Menkes Nomor 282/MENKES/SK/IV/1992 tentang Organisasi dan Tatakerja Balai Peagamanan Fasilitas Kesehatan, telah terbentuk 2 (dua) Balai Pengamanan Fasilitas Kesehatan (BPFK) yaitu BPFK Jakarta untuk melayani pengujian dan kalibrasi alat kesehatan pada sarana pelayanan kesehatan wilayah Indonesia bagian Barat dan BPFK Surabaya untuk Indonesia bagian Timur. BPFK sebagai unit pelaksana teknis pada Direktorat Jenderal Pelayanan Medik yang memiliki tugas dan fungsi untuk menyelenggarakan Pengujian dan Kalibrasi alat kesehatan adalah merupakan Institusi Penguji yang diselenggarakan oleh Pemerintah.

BPFK sebagai unit pelaksana teknis di bidang pengamanan fasilitas kesehatan di lingkungan Departemen Kesehatan yang berada di bawah Direktorat Jenderal Pelayanan Medik dengan tugas melaksanakan pengukuran, kalibrasi dan proteksi radiasi fasilitas kesehatan di lingkungan pemerintah maupun swasta. Untuk menyelenggarakan tugas tersebut BPFK mempunyai fungsi antara lain: (1) Melakukan pemeriksaan, pengukuran dan pengujian fasilitas kesehatan; (2) Melakukan peneraan fasilitas kesehatan; (3) Melakukan proteksi radiasi bagi pasien, tenaga kesehatan dan masyarakat.

Akurasi suatu alat kesehatan tidak dengan sendirinya timbul dari rancangan yang baik. Rancangan suatu alat kesehatan merupakan hasil kompromi antara kinerja, stabilitas, keandalan dan biaya serta faktor-faktor lain yang mempengaruhinya. Akurasi dapat diperoleh hanya dari kegiatan kalibrasi yang benar, sedangkan stabilitas dan keandalan dapat diketahui dari pengujian, atas dasar inilah perlunya dilakukan pengujian dan kalibrasi terhadap instrumen secara teratur. 
Pengujian dan kalibrasi alat kesehatan hanya dapat dilaksanakan oleh tenaga profesional, menggunakan alat ukur dan besaran standar yang terkalibrasi. Pengujian atau kalibrasi wajib dilakukan terhadap alat kesehatan dengan kriteria:

a. "Belum memiliki sertifikat dan tanda lulus pengujian atau kalibrasi.

b. Masa berlaku sertifikat dan tanda lulus pengujian atau kalibrasi telah habis.

c. Diketahui penunjukannya atau keluarannya atau kinerjanya (performance) atau keamanannya (safety) tidak sesuai lagi, walaupun sertifikat dan tanda masih berlaku.

d. Telah mengalami perbaikan, walaupun sertifikat dan tanda masih berlaku.

e. Telah dipindahkan bagi yang memerlukan instalasi, walaupun sertifikat dan tanda masih berlaku." 13

Usia pakai alat kesehatan dipengaruhi oleh kualitas pemeliharaan dan kondisi lingkungan. Inventarisasi alat kesehatan untuk keperluan pengujian atau kalibrasi adalah kegiatan pencatatan data peralatan kesehatan, termasuk perubahan data yang diperlukan dalam pelaksanaan pengujian atau kalibrasi alat kesehatan. Inventarisasi peralatan kesehatan dilaksanakan oleh Sarana Pelayanan Kesehatan, dalam hal ini dilakukan Instalasi Pemelihara Sarana Rumah Sakit (IPSRS) / Unit Pemelihara Alat Kesehatan atau unit lain yang diberi tugas, bekerja sama dengan pengelola barang / Inventarisasi Kekayaan Milik Negara. Daftar inventaris peralatan kesehatan wajib uji dan kalibrasi disimpan oleh IPSRS/ Unit Pemelihara Alat Kesehatan atau unit lain yang diberi tugas dan melaporkan secara berkala.

\section{Perlindungan Hukum Bagi Tenaga Kesehatan Di Bidang Radiologi Diagnostik}

Tujuan hukum untuk memberikan Pengayoman (Perlindungan) kepada manusia tersebut di dalamnya meliputi dua jenis perlindungan, yakni melindungi manusia baik secara pasif (negatif) dengan mencegah tindakan sewenang-wenang, maupun secara aktif (positif) dengan menciptakan kondisi kemasyarakatan yang manusiawi. Oleh karena itu, pelaksanaan dari "Pengayoman" tersebut harus dilakukan dengan usaha demi mewujudkan ketertiban dan keteraturan yang memunculkan prediktabilitas; kedamaian yang berketenteraman; keadilan (distributif, komutatif, vindikatif, protektif); kesejahteraan dan keadilan sosial; serta pembinaan akhlak luhur berdasarkan Ketuhanan Yang Maha Esa.

Hukum melalui fungsinya (sebagai sarana/instrumen) akan menjamin dan melindungi setiap subyek hukum dari tindakan sewenang-wenang dan pelanggaran hak. Selain itu, hukum juga melalui fungsinya (sebagai sarana/instrumen) berupaya untuk menciptakan kondisi sosial yang manusiawi sedemikian rupa, sehingga memungkinkan proses sosial berlangsung secara wajar, damai, tertib dan adil. Perlindungan hukum merupakan conditio sine quanon bagi terselenggaranya suatu proses kehidupan manusia yang bermartabat atau manusiawi. Oleh karena itu dalam konteks bermasyarakat, berbangsa dan bernegara, maka perlindungan hukum seharusnya diejawantahkan melalui suatu teks otoritatif agar masing-masing para subyek hukum (paling tidak/seyogianya) dapat melaksanakan hak dan kepentingan hukum yang dimilikinya.

Perlindungan yang diakomodir oleh hukum itu, sebagaimana yang dijabarkan oleh Teori Pengayoman adalah berupa perlindungan, baik yang bersifat pasif dengan pendekatan preventif maupun yang bersifat aktif berupa upaya pemulihan atau penyeimbangan terhadap pelanggaran hak yang terjadi. Hal ini ditujukan agar semua pihak atau para subyek hukum tadi dapat mengaktualisasikan hak dan kepentingan hukum yang dimilikinya.

Sehingga dengan demikian setiap warga negara ataupun segenap warga negara yang kapasitasnya adalah sebagai subyek hukum itu dapat melaksanakan hak dan kewajiban

${ }^{13}$ Lihat, PERMENKES No.363/MENKES/PER/IV/1998, pasal 2 ayat (2). 
mereka secara optimal dengan tenang dan tertib, yang karenanya pula akan terwujud suatu kondisi sosial kemasyarakatan yang aman dan sejahtera, di mana secara adil setiap manusia akan mendapatkan kesempatan yang seluas-luasnya untuk mengembangkan seluruh potensi kemanusiaannya secara utuh.

Untuk itu, perlindungan yang diberikan oleh hukum tersebut haruslah memenuhi unsur-unsur atau elemen-elemen tertentu yang terdapat dalam konsepsi perlindungan hukum itu. Adapun yang merupakan unsur-unsur yang terkandung dalam konsepsi perlindungan hukum ini, yaitu terdiri dari elemen-elemen sebagai berikut: Suatu jaminan yang diberikan oleh otoritas tertentu; Kepada semua pihak; Untuk dapat melaksanakan Hak dan Kepentingan Hukum yang dimilikinya; dan Dalam kapasitasnya sebagai subyek hukum.

Tenaga kesehatan di bidang radiologi diagnostik sebagai subyek hukum yang hak kewajibannya dilindungi sebagaimana diatur dalam atau oleh seperangkat aturan hukum yang terdiri dari: Pertama, Undang-Undang Nomor 36 Tahun 2009 Tentang Kesehatan. Kedua, Undang-Undang Nomor 44 Tahun 2009 Tentang Rumah Sakit. Ketiga, Undang-undang Republik Indonesia Nomor 10 tahun 1997 tentang Ketenaganukliran. Keempat, Peraturan Pemerintah Republik Indonesia Nomor 32 tahun 1996 tentang Tenaga Kesehatan. Kelima, Peraturan Pemerintah Republik Indonesia Nomor 33 tahun 2007 tentang Keselamatan Radiasi Pengion dan Keamanan Sumber Radioaktif. Keenam, Peraturan Pemerintah Republik Indonesia Nomor 29 tahun 2008 tentang Perizinan Pemanfaatan Sumber Radiasi Pengion dan Bahan Nuklir. Ketujuh, Peraturan Menteri Kesehatan Republik Indonesia Nomor 363/MENKES/PER/IV/1998 tentang Pengujian dan Kalibrasi Alat Kesehatan pada Sarana Pelayanan Kesehatan. Kedelapan, Peraturan Menteri Kesehatan Republik Indonesia Nomor 780/MENKES/PER/VIII/2008 tentang Penyelenggaraan Pelayanan Radiologi.

\section{Hubungan Ketentuan Tentang Keamanan Peralatan Radiasi Pengion Dan Perlindungan Hukum Bagi Tenaga Kesehatan Di Bidang Radiologi Diagnostik}

Aspek keselamatan dalam pemakaian tenaga nuklir di Indonesia dilindungi oleh Undang-undang Republik Indonesia Nomor 10 tahun 1997 tentang Ketenaganukliran, yang pelaksanaannya diatur oleh Peraturan Pemerintah Republik Indonesia Nomor 33 tahun 2007 tentang Keselamatan Radiasi Pengion dan Keamanan Sumber Radioaktif, Peraturan Pemerintah Republik Indonesia Nomor 29 tahun 2008 tentang Perizinan Pemanfaatan Sumber Radiasi Pengion dan Bahan Nuklir, dan Peraturan Menteri Kesehatan Republik Indonesia nomor 363/MENKES/PER/IV/1998 tentang Pengujian dan Kalibrasi Alat Kesehatan pada Sarana Pelayanan Kesehatan, serta Peraturan Menteri Kesehatan Republik Indonesia Nomor 780/MENKES/PER/VIII/2008 tentang Penyelenggaraan Pelayanan Radiologi.

Pemanfaatan Sumber Radiasi Pengion dan Bahan Nuklir dikelompokkan menjadi 3 (tiga) kelompok. Pengelompokan tersebut didasarkan pada risiko yang terkait dengan keselamatan radiasi dan keamanan Sumber Radioaktif dan Bahan Nuklir, dengan mempertimbangkan: potensi bahaya radiasi; tingkat kerumitan fasilitas dan/atau Sumber Radiasi Pengion dan Bahan Nuklir; jumlah dan kompetensi personil yang bekerja; potensi dampak kecelakaan radiasi terhadap keselamatan, kesehatan pekerja dan anggota masyarakat, dan lingkungan hidup; dan potensi ancaman terhadap Sumber Radioaktif dan Bahan Nuklir. Dalam hal ini Pemanfaatan Sumber Radiasi Pengion dan Bahan Nuklir dikelompokkan kedalam kelompok $\mathrm{A}$, yang merupakan kelompok dengan persyaratan izin paling ketat dibandingkan dengan kelompok $B$ dan kelompok $C$.

Pemanfaatan tenaga nuklir wajib dilaksanakan dengan memperhatikan aspek keselamatan dan keamanan untuk melindungi pekerja, anggota masyarakat, dan lingkungan hidup. Pengaturan mengenai Keselamatan Radiasi Pengion ditetapkan dengan Peraturan Pemerintah Nomor 33 Tahun 2007 tentang Keselamatan Radiasi Pengion dan Keamanan Sumber Radioaktif. 
Dalam ketentuan tersebut ditetapkan beberapa persyaratan keselamatan yang meliputi: (1) persyaratan Proteksi Radiasi; (2) limitasi Dosis; (3) verifikasi keselamatan dan persyaratan teknik; (4) pemantauan kesehatan pekerja yang lebih rinci; dan (5) intervensi dalam situasi kronik dan darurat.

Peraturan Menteri Kesehatan RI No. 363/Menkes/Per/IV/1998 tanggal 8 April 1998 tentang Pengujian dan Kalibrasi Alat Kesehatan, mewajibkan setiap alat kesehatan yang dipergunakan di Sarana Pelayanan Kesehatan dilakukan pengujian dan kalibrasi secara berkala sekurang-kurangnya 1 (satu) kali dalam setahun oleh institusi Penguji, untuk menjamin ketelitian dan ketepatan serta keamanan penggunaan alat kesehatan, sehingga dapat dipastikan kesesuaian alat kesehatan terhadap keselamatan kerja dan spesifikasinya. Kalibrasi alat kesehatan bertujuan untuk menjaga kondisi alat kesehatan agar tetap sesuai dengan standar besaran pada spesifikasinya. Dengan pelaksanaan kegiatan kalibrasi maka akurasi, ketelitian dan keamanan alat kesehatan dapat dijamin sesuai dengan besaranbesaran yang tertera/diabadikan pada alat kesehatan bersangkutan.

Berdasarkan uraian analisis yuridis mengenai hubungan ketentuan tentang keamanan peralatan radiasi pengion dan perlindungan hukum bagi tenaga kesehatan di bidang radiologi diagnostik tersebut di atas, dapat ditarik kesimpulan, yakni: "apabila ketentuan tentang keamanan peralatan radiasi pengion sebagaimana telah diuraikan tersebut di atas sungguhsungguh diterapkan dan dilaksanakan oleh para pihak yang berkaitan dengan itu, maka perlindungan hukum bagi tenaga kesehatan di bidang radiologi diagnostik akan terpenuhi."

\section{KESIMPULAN}

1. Keamanan Peralatan Radiasi Pengion; Apabila ketentuan - ketentuan / peraturan yang ada dijalankan maka jaminan keamanan peralatan Radiasi pengion akan dapa terpenuhi, sebagai penjelasan dijabarkan sebagai berikut.

a. Berdasarkan asalnya sumber radiasi pengion dapat dibedakan menjadi dua yaitu sumber radiasi alam yang sudah ada di alam ini sejak terbentuknya, dan sumber radiasi buatan yang sengaja dibuat oleh manusia untuk berbagai tujuan. Pengaruh radiasi pada organ tubuh manusia dapat bermacam-macam bergantung pada jumlah dosis dan luas lapangan radiasi yang diterima.

b. Makin tinggi paparan radiasi yang diterima oleh seseorang, maka makin tinggi pula risiko yang dapat ditimbulkannya. Dosis radiasi dalam berbagai ukuran yang diberikan dengan kecepatan yang berbeda terhadap bagian tubuh yang berbeda dapat menyebabkan efek kesehatan yang berbeda dalam kurun waktu yang berbeda pula.

c. Pemanfaatan Sumber Radiasi Pengion dan Bahan Nuklir dikelompokkan menjadi 3 (tiga) kelompok. Pengelompokan tersebut didasarkan pada risiko yang terkait dengan keselamatan radiasi dan keamanan Sumber Radioaktif dan Bahan Nuklir, dengan mempertimbangkan: potensi bahaya radiasi; tingkat kerumitan fasilitas dan/atau Sumber Radiasi Pengion dan Bahan Nuklir; jumlah dan kompetensi personil yang bekerja; potensi dampak kecelakaan radiasi terhadap keselamatan, kesehatan pekerja dan anggota masyarakat, dan lingkungan hidup; dan potensi ancaman terhadap Sumber Radioaktif dan Bahan Nuklir.

d. Pengaturan mengenai Keselamatan Radiasi Pengion ditetapkan dengan Peraturan Pemerintah Nomor 33 Tahun 2007 tentang Keselamatan Radiasi Pengion dan Keamanan Sumber Radioaktif. 
e. Penggunaan alat kesehatan di samping memberikan manfaat dapat pula menimbulkan dampak negatif yang merugikan. Oleh karena itu untuk menjamin kebenaran kelaikan penggunaan alat kesehatan dan agar alat kesehatan yang dimaksud tersebut berkualitas, maka perlu dilakukan pengujian dan kalibrasi sebagaimana diatur dalam Peraturan Menteri Kesehatan RI Nomor 363/Menkes/Per/IV/1998 tanggal 8 April 1998 tentang Pengujian dan Kalibrasi Alat Kesehatan, yang mewajibkan setiap alat kesehatan yang dipergunakan di Sarana Pelayanan Kesehatan dilakukan pengujian dan kalibrasi secara berkala sekurangkurangnya 1 (satu) kali dalam setahun oleh institusi Penguji, untuk menjamin ketelitian dan ketepatan serta keamanan penggunaan alat kesehatan.

f. Adapun untuk pemeliharaan dan perawatan peralatan radiologi tersebut, maka harus mengacu pada pedoman dari pabrikan yang dilakukan secara berkala dan berkelanjutan oleh radiographer, fisikawan medis, teknisi elektromedis dan teknisi pabrikan untuk menjamin mutu alat yang dipakai sehingga pelayanan kesehatan kepada masyarakat tidak terganggu. Hal ini sebagaimana diatur dalam Peraturan Menteri Kesehatan Nomor 780/Menkes/Per/VIII/2008 tentang Penyelenggaraan Pelayanan Radiologi dan Keputusan Menteri Kesehatan Nomor 1014/Menkes/SK/XI/2008 tentang Standar Pelayanan Radiologi Diagnostik di Sarana Pelayanan Kesehatan.

2. Perlindungan Hukum Bagi Tenaga Kesehatan Di Bidang Radiologi Diagnostik, untuk melindungi para pihak terkait dalam hubungan hukum, maka agar ketentuan-ketentuan yang dibuat benar-benar dapat melindungi para pihak, sebagai penjelasan dapat dijabarkan sebagai berikut :

a. Tujuan hukum bagi negara Indonesia adalah untuk memberikan Pengayoman (Perlindungan) kepada manusia tersebut di dalamnya meliputi dua jenis perlindungan, yakni melindungi manusia baik secara pasif (negatif) dengan mencegah tindakan sewenang-wenang, maupun secara aktif (positif).

b. Hukum melalui fungsinya (sebagai sarana/instrumen) akan menjamin dan melindungi setiap subyek hukum dari tindakan sewenang-wenang dan pelanggaran hak. Selain itu, hukum juga melalui fungsinya (sebagai sarana/instrumen) berupaya untuk menciptakan kondisi sosial yang manusiawi sedemikian rupa, sehingga memungkinkan proses sosial berlangsung secara wajar, damai, tertib dan adil.

c. Sehingga perlindungan hukum seharusnya diejawantahkan melalui suatu teks otoritatif agar masing-masing para subyek hukum (paling tidak/seyogianya) dapat melaksanakan hak dan kepentingan hukum yang dimilikinya.

d. Setiap warga negara yang kapasitasnya adalah sebagai subyek hukum itu dapat melaksanakan hak dan kewajiban mereka secara optimal dengan tenang dan tertib, yang karenanya pula akan terwujud suatu kondisi sosial kemasyarakatan yang aman dan sejahtera, di mana secara adil setiap manusia akan mendapatkan kesempatan yang seluasluasnya untuk mengembangkan seluruh potensi kemanusiaannya secara utuh, maka hukum haruslah dapat melindungi para subyek hukum tersebut yang dalam hal ini khususnya adalah tenaga kesehatan di bidang radiologi diagnostik terhadap keamanan peralatan yang digunakannya.

e. Oleh karena itu perlindungan yang diberikan oleh hukum tersebut haruslah memenuhi unsur-unsur atau elemen-elemen tertentu yang terdapat dalam konsepsi perlindungan hukum itu. Adapun yang merupakan unsur-unsur yang terkandung dalam konsepsi perlindungan hukum ini, yaitu terdiri dari elemen-elemen sebagai berikut: suatu jaminan yang diberikan oleh otoritas tertentu; kepada semua pihak; untuk dapat melaksanakan hak dan kepentingan hukum yang dimilikinya; dan dalam kapasitasnya sebagai subyek hukum. 
f. Adapun perangkat aturan hukum yang memberikan perlindungan bagi tenaga kesehatan di bidang radiologi diagnostik sebagai subyek hukum yang hak kewajibannya dilindungi adalah terdiri dari: Pertama, Undang- Undang Nomor 36 Tahun 2009 Tentang Kesehatan. Kedua, Undang- Undang Nomor 44 Tahun 2009 Tentang Rumah Sakit. Ketiga, Undangundang Republik Indonesia Nomor 10 tahun 1997 tentang Ketenaganukliran. Keempat, Peraturan Pemerintah Republik Indonesia Nomor 32 tahun 1996 tentang Tenaga Kesehatan. Kelima, Peraturan Pemerintah Republik Indonesia Nomor 33 tahun 2007 tentang Keselamatan Radiasi Pengion dan Keamanan Sumber Radioaktif. Keenam, Peraturan Pemerintah Republik Indonesia Nomor 29 tahun 2008 tentang Perizinan Pemanfaatan Sumber Radiasi Pengion dan Bahan Nuklir. Ketujuh, Peraturan Menteri Kesehatan Republik Indonesia Nomor 363/MENKES/PER/IV/1998 tentang Pengujian dan Kalibrasi Alat Kesehatan pada Sarana Pelayanan Kesehatan. Kedelapan, Peraturan Menteri Kesehatan Republik Indonesia Nomor 780/MENKES/PER/VIII/2008 tentang Penyelenggaraan Pelayanan Radiologi.

3. Keamanan Peralatan Radiasi Pengion Dikaitkan Dengan Perlindungan Hukum Bagi Tenaga Kesehatan Di Bidang Radiologi Diagnostik, "jika ketentukan tentang keamanan peralatan radiasi pengion sebagaimana telah diuraikan tersebut di atas sungguh-sungguh diterapkan dan dilaksanakan oleh para pihak yang berkaitan dengan itu, maka perlindungan hukum bagi tenaga kesehatan di bidang radiologi diagnostik akan terpenuhi”

\section{SARAN}

1. Agar diberikan informasi dini kepada para petugas kesehatan khususnya pekerja kesehatan di bidang Radiologi diagnostik tentang ketentuanketentuan keselamatan Radiasi untuk mencegah penggunaan radiologi diagnostik yang tidak sesuai dengan prinsip dasar keselamatan radiasi yang dapat membahayakan kesehatan pasien, tenaga kesehatan maupun masyarakat di sekitarnya.

2. Agar para penyelenggara sarana pelayanan kesehatan dan para Tenaga Kesehatan khususnya di bidang Radilogi diagnostik dalam melaksanakan pemberian pelayanan Radiologi diagnostik memenuhi aturan keselamatan, untuk menjamin perlindungan hukum terhadap pekerja tersebut.

3. Agar dilakukan evaluasi berkala tentang penerapan ketentuan-ketentuan tentang keselamatan penggunan sinar pengion, untuk mengantisipasi bahaya kesehatan akibat penggunaan Radiologi diagnostic dan untuk menjaga mutu pelayanan radiologi diagnostik disarana pelayanan kesehatan.

4. Agar dibentuk peraturan setingkat undang-undang, yang mengatur tentang perlindungan

\section{DAFTAR PUSTAKA}

Oka Mahendra, Proses Pemantapan Cita Hukum dan Penerapan Asas-asas Hukum Nasional Masa Kini dan di Masa yang Akan Datang dalam "Majalah Hukum Nasional” Nomor 1 Tahun 1995, BPHN Departemen Kehakiman.

Sonny Keraf \& Mikhael Dua, Ilmu Pengetahuan (Sebuah Tinjauan Filosofis), Kanisius, Yogyakarta, 2001;

A. Hamid S. Attamimi, Peranan Keputusan Presiden Republik Indonesia Dalam Penyelenggaraan Pemerintahan Negara, Disertasi Program Studi Doktor Ilmu Hukum Universitas Indonesia, Jakarta, 1990. 
Abdulkadir Besar, Implementasi Cita Hukum dan Penerapan Asas-asas Hukum Nasional Sejak Lahirnya Orde Baru dalam "Majalah Hukum Nasional” No. 1 Tahun 1995, Pusat Dokumentasi Hukum BPHN Departemen Kehakiman.

Abdul Ghofur Anshori, Filsafat Hukum, Gadjah Mada University Press, Yogyakarta, 2006.

Arief Sidharta, Refleksi Tentang Struktur Ilmu Hukum, Mandar Maju, Bandung, 2000.

Darji Darmodiharjo \& Shidarta, Penjabaran Nilai-nilai Pancasila Dalam Sistem Hukum Indonesia, Rajawali Pers, Jakarta, 1996.

Herlien Budiono, Asas Keseimbangan Bagi Hukum Perjanjian Indonesia diterjemahkan oleh: Tristam P. Moeliono, Citra Aditya Bakti, Bandung, 2006.

Hilman Hadikusuma, Metode Pembuatan Kertas Kerja atau Skripsi Ilmu Hukum, Mandar Maju, Bandung, 1995.

J. J. H. Bruggink, Refleksi Tentang Hukum diterjemahkan oleh: B. Arief Sidharta, Citra Aditya Bakti, Bandung, 1999.

Johannes Ibrahim, Pengimpasan Pinjaman (Kompensasi) dan Asas Kebebasan Berkontrak Dalam Perjanjian Kredit Bank, Utomo, Bandung, 2003.

Krisnajadi, Bab-bab Pengantar Ilmu Hukum Bagian I, Sekolah Tinggi Hukum Bandung, Bandung, 1989.

Lawrence M. Friedman, Hukum Amerika (Sebuah Pengantar) diterjemahkan oleh: Wishnu Basuki, Tatanusa, Jakarta, 2001.

Mochtar Kusumaatmadja \& B. Arief Sidharta, Pengantar Ilmu Hukum, Alumni, Bandung, 2001.

Moh. Nazir, Metode Penelitian, Ghalia Indonesia, Jakarta, 1985.

Purnadi Purbacaraka \& Soerjono Soekanto, Perihal Kaedah Hukum, Alumni, Bandung, 1982.

Roeslan Saleh, Pembinaan Cita Hukum dan Penerapan Asas-asas Hukum Nasional dalam "Majalah Hukum Nasional" Nomor 1 Tahun 1995 BPHN Departemen Kehakiman.

Samsi Yakobalis, Rumah Sakit Indonesia dalam Dinamika Sejarah, Transformasi, Globalisasi dan Krisis Nasional, Penerbit IDI, Jakarta, 2000.

Satjipto Rahardjo, Hukum Dalam Jagat Ketertiban, UKI Press, Jakarta, 2006.

Satjipto Rahardjo, Ilmu Hukum, Citra Aditya Bakti, Bandung, 2000.

Satjipto Rahardjo, Biarkan Hukum Mengalir (Catatan Kritis Tentang Pergulatan Manusia dan Hukum), Kompas, Jakarta, 2007.

Sedarmayanti \& Syarifudin Hidayat, MetodologiPenelitian, Mandar Maju, Bandung, 2002.

Soediman Kartohadiprodjo, Pantja Sila (Suatu Usaha Percobaan Mendekati Problema Sekitarnya) dalam “Kumpulan Karangan”, Pembangunan, Jakarta, 1965.

Soediman Kartohadiprodjo, Beberapa Pikiran Sekitar Pancasila, Alumni, Bandung, 1983.

Soediman Kartohadiprodjo, Penglihatan Manusia Tentang Tempat Individu Dalam Pergaulan Hidup (Suatu Masalah) dalam “Kumpulan Karangan”, Pembangunan, Jakarta, 1965.

Soediman Kartohadiprodjo, Pengantar Tata Hukum di Indonesia, Pembangunan \& Ghalia Indonesia, Jakarta, 1987.

Soedjono Dirdjosisworo, Pengantar Ilmu Hukum, RajaGrafindo Persada, Jakarta, 1994; 
Soerjono Soekanto \& Sri Mamudji, Penelitian Hukum Normatif (Suatu Tinjauan Singkat), Rajawali Pers, Jakarta, 2001.

Sofwan Dahlan, Hukum Kesehatan (Rambu-rambu Bagi Profesi Dokter), Badan Penerbit UNDIP, Semarang, 2005.

Sudikno Mertokusumo, Penemuan Hukum (Sebuah Pengantar), Liberty, Yogyakarta, 2000.

Sudikno Mertokusumo, Mengenal Hukum (Suatu Pengantar), Liberty, Yoyakarta, 2002;

Theo Huijbers, Filsafat Hukum, Kanisius, Yogyakarta, 1995.

Wila Chandrawila Supriadi, Hukum Kedokteran, Mandar Maju, Bandung, 2001. 